Authors:

Li Junfeng

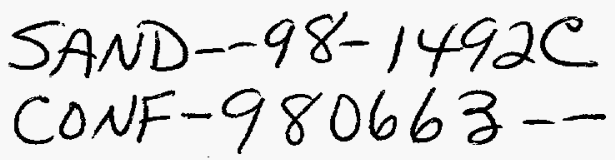

Zhu Li

Center For Renewable Energy Development, Energy Research Institute (China)

Liu Zhan

Zhang Yuan

State Power Company (China)

Byron Washom (Spencer Management Associates, USA)

Gregory Kolb (Sandia National Laboratories", Sun̨ $\bullet$ Lab, USA)

RECEIVED

JUL 071998

OSTI

\title{
Initial Appraisal of Solar Thermal Electric Energy in Tibet and Xinjiang Provinces, People's Republic of China
}

\begin{abstract}
At the request of USA sponsors Spencer Management Associates (SMA) and Sun`Lab, China's Center for Renewable Energy Development and former Ministry of Electric Power conducted an initial appraisal of the issues involved with developing China's first solar thermal electric power plant in the sunbelt regions of Tibet or Xinjiang provinces. The appraisal concerns development of a large-scale, grid-connected solar trough or tower project capable of producing 30 or more megawatts of electricity. Several of the findings suggest that Tibet could be a niche market for solar thermal power because a solar plant may be the low-cost option relative to other methods of generating electricity.
\end{abstract}

China has studied the concept of a solar thermal power plant for quite some time. In 1992, it completed a pre-feasibility study for a SEGS-type parabolic trough plant with the aid of Israel's United Development Limited. Because the findings were positive, both parties agreed to conduct a full-scale feasibly study. However, due to funding constraints, the study was postponed. Most recently, Sun $\bullet$ Lab and SMA asked China to broaden the analysis to include tower as well as trough concepts. The findings of this most recent investigation, completed in November of 1997, are the subject of this paper. The main conclusions of all studies conducted to date suggest that a region in the proximity of Lhasa, Tibet, offers the best near-term opportunity within China. The opportunities for solar thermal power plants in other regions of China were also investigated.

* Sandia is a multiprogram laboratory operated by Sandia Corporation, a Lockheed Martin Company, for the United States Department of Energy under Contract DE-ACO494AL85000. 


\section{DISCLAIMER}

This report was prepared as an account of work sponsored by an agency of the United States Government. Neither the United States Government nor any agency thereof, nor any of their employees, makes any wartanty, express or implied, or assumes any legal liability or responsibility for the accuracy, completeness, or usefulness of any information, apparatus, product, or process disclosed, or represents that its use would not infringe privately owned rights. Reference herein to any specific commercial product, process, or service by trade name, trademark, manufacturer, or otherwise does not necessarily constitute or imply its endorsement, recommendation, or favoring by the United States Government or any agency thereof. The views and opinions of authors expressed herein do not necessarily state or reflect those of the United States Government or any agency thereof. 


\section{DISCLAIMER}

Portions of this document may be illegible electronic image products. Images are produced from the best available original document. 


\section{INTRODUCTION}

China has an abundant solar resource, especially in Tibet, a region with one of the harshest geographic and climatic conditions in the world, and where it is difficult to have any reliable source of energy. In 1992, China and Israel United Development Limited completed a pre-feasibility study for a 35-MW solar thermal plant in Lhasa, Tibet, which included assessing the environmental and siting conditions there, studying existing power systems, an making an economic analysis. This effort resulted in an agreement by both parties to make a full feasibility study, but because of funding issues, it has been postponed. In 1995, the U.S. National Renewable Energy Laboratory also reviewed a proposal for a 35-MW parabolic trough solar thermal electric power plant in Lhasa, Tibet based on the pre-feasibility study, and it concluded that Tibet appears to be a unique niche market for a solar thermal electric power plant. NREL suggested that a more detailed analysis be made to optimize the size of the solar plant so as to integrate Lhasa's other power-generation facilities.

\section{GENERAL OVERVIEW OF THE PROPOSED LHASA, TIBET PROJECT}

\subsection{Site}

\subsubsection{Meteorology}

Tibet in general is a very mountainous region, and there are limited sites that would be ideally suited for a large parabolic trough plant. One of them is Lhasa, the capital of this province, which covers an area of 19.3 million square kilometers with a complicated topography, and a population of 342,000 . The average altitude is 3700 meters. Lhasa's solar resource is so abundant that it is called "Sunlight City." Solar data analyzed from Lhasa included monthly total solar, diffuse solar, and beam component as measured on a horizontal surface, and it all indicates very high annual total solar radiation. However, for more accurate estimates of the potential electrical output of a solar plant, hourly solar radiation will be needed.

The average wind speed in the Lhasa area is about $2.1 \mathrm{~m} / \mathrm{s}$, with the maximum at about $3.8 \mathrm{~m} / \mathrm{s}$; thus wind should not be a problem for a solar thermal power plant. In addition, a moderate ambient temperature is ideal for such a plant, and that is what is found in Lhasa.

\subsubsection{Infrastructure}


Road access to Lhasa is likely to be the major problem in building this type of plant. All imported materials will have to be shipped to the port of Tianjing, then transported by rail to Geermu in Qinghai Province or to Chendu, Sichuan Province. There are two access roads into Tibet: one the Sichuan-Tibet Road, the other the Qinghai-Tibet Road, which is a second-level national road, about 7 meters wide and in good condition. All materials could then be shipped by truck the rest of the 1500 $\mathrm{km}$ to Lhasa. In addition, there are daily flights from Lhasa to Xian, Sichun, and Beijing.

At the proposed site on the floor of the Lhasa river basin adjacent to city of Lhasa, the solar plant could make a transmission interconnection to the existing $100-\mathrm{kV}$ grid and should not pose a problem or result in any significant cost. The distance of the proposed solar plant site to the grid is about $5-10 \mathrm{~km}$.

This site has access to sufficient water, because the Lhasa river has an average flow of $26.5 \mathrm{~m}^{3} / \mathrm{sec}$ during the dry season, The underground water supply at this site is also abundant, and it is at 1-2 meters from the surface. This is sufficient to supply water for the cooling tower, for which approximately $0.04 \mathrm{~m}^{3} / \mathrm{sec}$ would be required. River water could also be used for cooling, but a temperature increase of $0.8^{\circ} \mathrm{C}$ could be experienced during the dry season. Additional study would be required to determine if this rise in temperature is significant. Alternatively, a well could be dug at the site to provide water to cool the power plant.

By the year 2000, the Lahsa grid will be at $170 \mathrm{MW}$, because of the $90-\mathrm{MW}$ hydro power plant built at Yanghu in 1995. A 30 to 100-MW solar thermal power plant would match it very well. However, since Lhasa is a very mountainous area, siting the solar plant seems to be the major problem. An existing geothermal power plant could be the back-up for the solar thermal plant.

\subsection{Electricity Power Potential in Lhasa Grid}

There are no statistics on electricity for all of Tibet. Most of the province has no grid power; the main grid is the Lhasa-Zedang grid, with $160 \mathrm{MW}$ total capacity. The province does have geothermal plants, namely the Yangyi, Naqu, Longjiu, and Yangbajing facilities. Geothermal accounts for $55 \%$ of the total grid power in Tibet, or nearly $10.8 \mathrm{MWh}$ in 1994 . For example, the Yangbajing geothermal plant is within a rifting basin about $90 \mathrm{~km}$ north of Lhasa; the total capacity installed is $25.18 \mathrm{MW}$. It could be expanded to $30-35 \mathrm{MW}$ before the year 2000 , but this is not enough to satisfy the power demand in Tibet.

Because of the extremely harsh geography in Tibet, hydro, geothermal and solar energy can compete economically with conventional energy power generation. To the present, hydro and geothermal have been developed, but because the geothermal and hydro resources are limited, these sources of energy cannot satisfy the power demand in Tibet. 
No matter what kind of power plant is built in Tibet, the price for power will have to be subsidized because of the geography and the province's lack of economic development. However, the Tibetan grid is smaller than in any other province, and it will be much easier to negotiate the price of power there. On the positive side, the local government supports a solar thermal plant, and, in addition, its price for power has the same incentive as for geothermal and hydro power in Lhasa: the resource is free. The main barrier to constructing a solar thermal power plant in Tibet seems to be the finances.

Current and planned power plant in Lhasa Grid

\begin{tabular}{|l|l|l|l|}
\hline & Power plant & $\begin{array}{l}\text { Capacity } \\
\text { Installed }\end{array}$ & $\begin{array}{l}\text { Capacity } \\
\text { planned }\end{array}$ \\
\hline 1. & Yangbajing Geothermal Plant & $25 \mathrm{MW}$ & $30-35 \mathrm{MW}$ \\
\hline 2. & Laha Diesel Plant & $16 \mathrm{MW}$ & \\
\hline 3. & Najin Hydro Plant & $25 \mathrm{MW}$ & \\
\hline 4. & Xianduo Hydro Plant & $2.6 \mathrm{MW}$ & \\
\hline 5. & Pingcuo Hydro Plant & $6 \mathrm{MW}$ & \\
\hline 6. & Yanghu hydro Plant & $90 \mathrm{MW}$ & $108 \mathrm{MW}$ \\
\hline
\end{tabular}

The Electricity Power and Fuel Cost in Tibet

\begin{tabular}{|l|l|}
\hline Fuel & Electricity power Cost \\
\hline Diesel & $1.80-2.40 \mathrm{Yuan} / \mathrm{kWh}$ \\
\hline Hydro power & $1.7 \mathrm{Yuan} / \mathrm{kWh}$ \\
\hline Geothermal & $1.5 \mathrm{Yuan} / \mathrm{kWh}$ \\
\hline Power Price (Subsided) & $0.4 \mathrm{Yuan} / \mathrm{kWh}$ \\
\hline
\end{tabular}

The pre-feasibility study for the proposed 35-MW parabolic trough solar thermal electricity power plant in Lhasa shows that the electricity output from a parabolic trough plant would coincide with one of the two daily peak electricity demand periods. If thermal storage were added to the project, the solar plant could also produce power during the second nighttime peak electricity demand period.

The daily power load in Lhasa in 1994

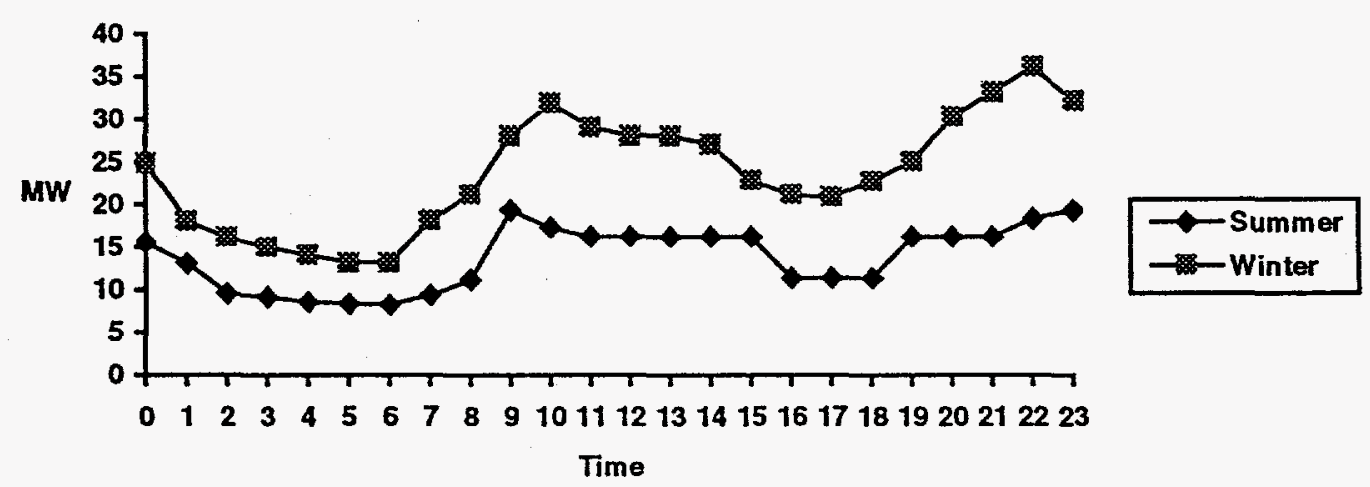




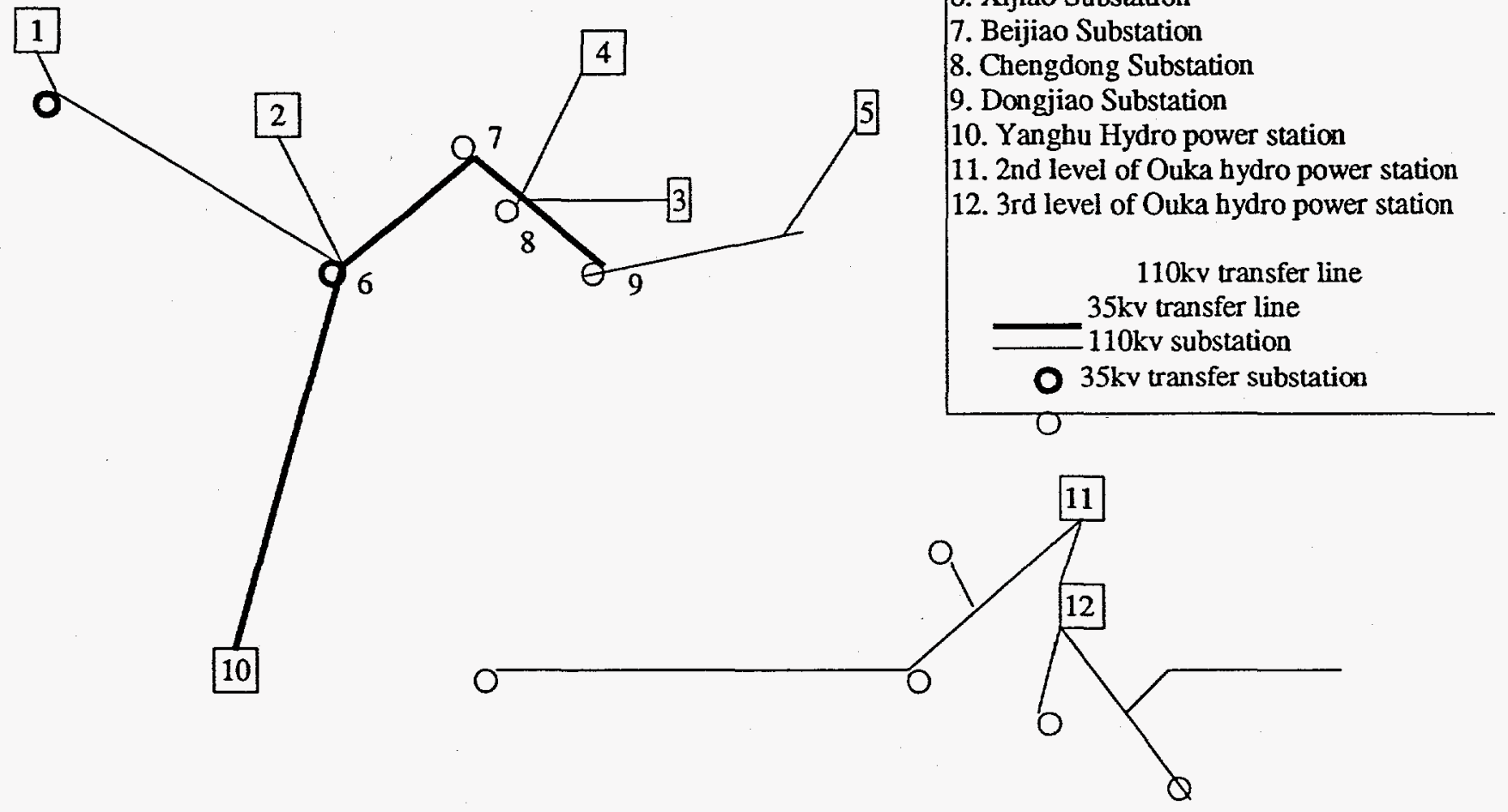

1 Yangbajing Geothermal plant

2. Lhasa Power Plant

3. Najin Hydro power plant

4. Xiangduo Hydro power plant

5. Pingcou Hydro power plant

6. Xijiao Substation

7. Beijiao Substation

8. Chengdong Substation

9. Dongjiao Substation

10. Yanghu Hydro power station

11. 2nd level of Ouka hydro power station

12. 3rd level of Ouka hydro power station

$110 \mathrm{kv}$ transfer line $35 \mathrm{kv}$ transfer line 110kv substation

$35 \mathrm{kv}$ transfer substation 


\section{OPPORTUNITIES FOR SOLAR THERMAL ELECTRIC TECHNOLOGIES IN XINJIANG}

Xinjiang's solar resource is the second richest in China, however, Xinjiang also has abundant coal, oil and natural gas. Although Xinjiang has a shortage of power, no solar thermal power plant has been considered for this location, and no feasibility study has been made for this type of plant. The price for power in Xinjiang is fairly low, and the government does not subsidize the rate. On the other hand, Xinjiang has 480,000 households without electricity in remote areas far from the existing grid, and the government has made rural electrification a high priority.

The power supply status in Xinjing

\begin{tabular}{llll}
\hline Item & Electricity Power Consumption & $\begin{array}{l}\text { Power } \\
(\text { Yuan } / \mathrm{kWh})\end{array}$ & Price \\
\hline Industry sector & $10.4 \mathrm{TWh}$ & $0.3-1.00$ \\
Institutional sector & $0.6 \mathrm{TWh}$ & 0.45 \\
Residential sector & $0.8 \mathrm{TWh}$ & 0.45 \\
\hline
\end{tabular}

Because a parabolic trough power plant is the only type of solar thermal technology that is currently commercially available, the province of Xinjiang is likely to be a potential market.

\section{FINANCIAL INCENTIVES TO USE RENEWABLE ENERGY IN CHINA}

Since the early 1980s, the Government of China has paid great attention to the development of renewable energy technologies. For more than twenty years, renewable energy has been a major part of the energy development strategy in China and has taken a very important role in its energy supply, especially for the rural remote areas.

To help with rural electrification and with local and global environmental improvement, Chinese governmental agencies concerned with developing renewable energy completed a study of financial incentives to develop renewable energy with the assistance of the World Bank. The study analyzed the experiences of other developed countries and drew up recommendations for the State Council of China. Consequently, the state council issued an import taxation incentive relative to renewable energy systems last year.

Because China does not yet have a solar thermal power plant, there is no specific incentive for solar thermal technology development. However, national and local government agencies are working on solar thermal power plant projects, and it can be assumed that if there is funding available either from international agencies or bilateral government assistance, a solar thermal power plant can take advantage of recent tax incentives and the IPP standard, which will be enforced at the World Bank Wind Power Project. 


\section{THE RECOMMENDATIONS FOR THE NEXT STEP}

Chinese agencies have made a pre-feasibility study for a $35-\mathrm{W}$ solar thermal power plant, and a more detailed study is recommended to move the Tibet project toward project implementation. Specifically needed are the following:

- Hourly solar radiation data for the specific project region and for other potential sites in China

- Installed instruments to measure direct normal radiation at the proposed site.

- An optimized design for the proposed plant at the Lhasa Grid.

- A developed project implementation plan to move the project forward, including international finance agencies and a technical research institute as well as Chinese agencies.

\section{References:}

[1]. "35MW Parabolic Trough Solar Thermal Electric Power Plant in Lhasa, Tibet," Tibet Electric Power Bureau, 1994.

[2]. "Review of a Proposed 35 MW Parabolic Trough Solar Thermal Electric Power Plant in Lhasa, Tibet," National Renewable Energy Laboratory, 1995.

[3]. Tibet Statistics Year Book. National Statistics Bureau of China, 1995.

[4]. Xinjiang Statistics Year Book, National Statistic Bureau of China, 1995. 